\title{
Demographic implications of alternative foraging strategies in juvenile loggerhead turtles Caretta caretta of the North Pacific Ocean
}

\author{
S. Hoyt Peckham ${ }^{1,2 *, * *}$, David Maldonado-Diaz ${ }^{1}$, Yann Tremblay ${ }^{3,2 *}$, Ruth Ochoa ${ }^{1,4}$, \\ Jeffrey Polovina ${ }^{5}$, George Balazs ${ }^{5}$, Peter H. Dutton ${ }^{6}$, Wallace J. Nichols ${ }^{7}$ \\ ${ }^{1}$ Grupo Tortuguero de las Californias, La Paz, Baja California Sur, CP 23060, Mexico \\ ${ }^{2}$ Department of Ecology and Evolutionary Biology, UC Santa Cruz, Santa Cruz, California 95060, USA \\ ${ }^{3}$ Institut de Recherche pour le Développement (IRD), Centre de Recherche Halieutique Méditerranéenne \\ et Tropicale (CRH), UMR-212 Exploited Marine Ecosystems (EME), 34203 Sète, France \\ ${ }^{4}$ Centro de Investigaciones Biológicas del Noroeste, La Paz, Baja California Sur, 23090 Mexico \\ ${ }^{5}$ Pacific Islands Fisheries Science Center, NOAA Fisheries, Honolulu, Hawaii 96822, USA \\ ${ }^{6}$ Southwest Fisheries Science Center, NOAA Fisheries, La Jolla, California 92037, USA \\ ${ }^{7}$ California Academy of Sciences, San Francisco, California 94118, USA
}

\begin{abstract}
To assess the potential demographic consequences of alternative juvenile foraging strategies in loggerhead sea turtles Caretta caretta, we compared habitat selection, movement, size frequency, and diet of juvenile loggerheads in neritic versus oceanic habitats of the North Pacific. Forty juveniles satellite-tracked from neritic habitat revealed utilization distributions 2 orders of magnitude smaller than those of 26 juveniles of the same size class tracked for similar durations from oceanic habitat. Oceanic juveniles traveled significantly further, faster and straighter, experienced lower sea surface temperature and productivity, and consumed prey of much lower energy density, strongly suggesting that the neritic foraging strategy is energetically favorable. These findings combined with those from other studies suggest that the neritic strategy would result in higher growth and eventually higher fecundity. Manipulation of a loggerhead demographic model indicated that small disadvantages in survivorship for neritic juveniles could balance the relatively large advantages in growth and fecundity of the neritic strategy. The oceanic strategy may persist as a slower but safer life history strategy. Our findings underscore the importance of elucidating variation in the ecology and corresponding vital rates of juveniles for modeling, managing, and conserving migratory megafaunal populations.
\end{abstract}

KEY WORDS: Demography · Ontogeny · Diet · Juvenile $\cdot$ Migration $\cdot$ Habitat use $\cdot$ Utilization distributions

Resale or republication not permitted without written consent of the publisher

\section{INTRODUCTION}

Marine megafauna such as cetaceans, sea birds, sharks, and sea turtles are especially vulnerable to depletion as a result of their slow life histories (Heppell et al. 1999, Baum et al. 2003). Because they are longlived, slow-growing, and late to reproduce, their population dynamics are particularly sensitive to changes in growth and mortality of older juveniles and adults (Crowder et al. 1994, Crouse 1999, Heppell et al. 1999). Despite the demographic importance of large juve- niles, their ecology and life history remain poorly understood for large, migratory, marine vertebrates.

Delayed maturity, high mobility, and freedom from having to return to a central location to reproduce enable juvenile megafauna to choose among oceanwide habitats and foraging strategies. Because prey availability, predation risk, and other factors often vary between habitats, differential habitat use and corresponding foraging strategies may result in differential growth, survival, and ultimately fecundity among individuals of the same species or population (Skulason \& 
Smith 1995, Bolnick et al. 2003). Variation in the foraging strategies of juveniles and their resulting vital rates could have profound implications for the demography and conservation of migratory megafauna.

Loggerhead turtles Caretta caretta exhibit several life history patterns that make them useful subjects for examining the effects of alternative foraging strategies. During their long juvenile life stage, which lasts upwards of 3 decades (Snover 2002, Heppell et al. 2003), these individuals are opportunistically omnivorous and capable of transoceanic movements. They have no parental care or social structure and they are not tied to a central location for reproduction, enabling them to choose from an ocean-wide range of habitats (Bolten 2003). As juveniles, loggerheads use both oceanic and neritic habitats (Pitman 1990, Polovina et al. 2000, Bolten 2003, McClellan \& Read 2007).

In the Atlantic Ocean, Caretta caretta have long been thought to undergo an ontogenetic habitat shift from oceanic to neritic habitats upon reaching a size threshold of $\sim 48 \mathrm{~cm}$ (Carr 1987, Bjorndal et al. 2000, Bolten 2003), though recent data support more flexibility in the large juvenile stage. Based on annual ring spacing in sectioned humeri, Snover (2002) found that large juvenile loggerheads in the Atlantic may experience as much as a $30 \%$ increase in growth rates after shifting from oceanic to neritic habitats, suggesting that foraging in neritic habitats is highly advantageous. This is presumably due to higher availability and quality of prey in neritic compared to oceanic habitats (Snover 2002). As a result of this difference in growth rate, habitat choice may have important indirect effects on demographic rates. However, a growing body of evidence suggests that this ontogenetic shift may be facultative and reversible, and that some juveniles may remain in (or return to) oceanic habitats until reaching maturity, despite the potential growth advantages of neritic foraging (Polovina et al. 2006, McClellan \& Read 2007, Mansfield et al. 2009, McClellan et al. 2010).

Nesting loggerheads tracked from Japanese and North Atlantic rookeries show within-population differences in habitat use that are distinct enough to be considered a trophic polymorphism (Hatase et al. 2002, Hawkes et al. 2006, 2007). In these populations, adult females that forage in productive neritic habitats are significantly larger than those foraging in oligotrophic oceanic habitats. Because growth in sea turtles is negligible once reproductive maturity is reached (Carr \& Goodman 1970, Broderick et al. 2003, Limpus \& Limpus 2003), it is possible that individuals foraging in neritic habitats mature earlier and/or at larger sizes than those foraging in oceanic habitats (Hatase et al. 2002, Hawkes et al. 2006). First-time neritic nesters were significantly larger than oceanic nesters at Yakushima Island, Japan, and a promising new aging tech- nique suggested they were of similar ages (Hatase et al 2010). Though not yet tested empirically, a reasonable hypothesis is that larger, neritic-foraging nesters may have greater lifetime reproductive output because they mature earlier and fecundity increases with size in loggerheads (Frazer \& Richardson 1986, Tiwari \& Bjorndal 2000, Broderick et al. 2003).

Juvenile loggerheads in the North Pacific leave their Japanese rookeries as hatchlings and are known to frequent 2 regions, the oceanic Central North Pacific (CNP) and neritic habitats of the Baja California Peninsula, Mexico (BCP). Because the oceanographic factors that produce prey in the 2 regions are different (Espinosa-Carreon et al. 2004, Legaard \& Thomas 2006, Palacios et al. 2006, Polovina et al. 2006), patterns of prey abundance and quality also differ between these regions. In the CNP, juvenile loggerheads feed opportunistically on patchily distributed epipelagic prey (Parker et al. 2005), and they move thousands of $\mathrm{km}$ each year tracking these prey through fronts and eddies in relatively cold water (Polovina et al. 2000, 2004, 2006, Howell et al. 2008, Kobayashi et al. 2008). At the BCP, juvenile loggerheads frequent a coastal high-use area (Peckham et al. 2007), and they feed primarily on pelagic red crabs Pleuroncodes planipes (Ramirez-Cruz et al. 1991, Nichols 2003).

Given the probable advantages of neritic foraging in terms of both juvenile growth and adult fecundity (Hatase et al. 2002, 2007, Snover 2002, Hawkes et al. 2006), alternative foraging strategies between juvenile loggerheads in the North Pacific could convey large differences in fitness. In the present study, we evaluate this general hypothesis by directly comparing the diet, movement, habitat use, and size frequency of juvenile loggerheads between neritic BCP and oceanic CNP habitats, representing the first comparison of juvenile sea turtle ecology between oceanic and neritic habitats. Based on these results, we then used an existing loggerhead demographic model to explore how these alternative juvenile strategies might differ in their contributions to population growth.

\section{MATERIALS AND METHODS}

Satellite telemetry. The movements of loggerhead turtles were monitored using satellite transmitters deployed on 63 individuals. In the CNP, observers on Hawaii-based longline fishing vessels attached Argos satellite-linked transmitters to 23 loggerhead turtles taken as bycatch from 1997 to 2001 . At the BCP, a total of 40 loggerheads were either captured by hand from small fishing boats (38 individuals) or retrieved living from bottom-set longlines (2 individuals), instrumented, and released as above from 1996 to 2007. Satellite 
transmitters were attached to turtle carapaces using polyester resin and fiberglass cloth (Balazs et al. 1996) and monitored via the Argos satellite system. Portions of this loggerhead satellite telemetry dataset have been used to examine distributional relationships with oceanographic fronts (Polovina et al. 2000), diving behavior (Polovina et al. 2003), and foraging behavior (Polovina et al. 2004), and to characterize high-use areas (Polovina et al. 2006, Peckham et al. 2007), bycatch rates (Peckham et al. 2007), and pelagic habitat use (Kobayashi et al. 2008). Here we present 14 new tracks in addition to tracks previously reported from the BCP (Nichols et al. 2000; Peckham et al. 2007).

Movement analysis. Raw Argos-derived positions from all tracks were filtered based on a maximum rate of travel of $5 \mathrm{~km} \mathrm{~h}^{-1}$. In order to obtain data that were equally spaced temporally, we interpolated consecutive ARGOS hits every $12 \mathrm{~h}$ following the methods of Tremblay et al. (2006). We determined multiindividual utilization distributions (UDs) with a Gaussian kernel density analysis of the positions from tracks from each habitat. From the combined dataset of all interpolated positions, an index of turtle residence probability per unit area was derived as follows: (1) the number of locations per $5 \mathrm{~km}^{2}$ cell was calculated and (2) each of these totals was weighted by multiplying it by the number of individual turtles using that cell. In this way, cells frequented by more individuals for extended periods of time were given more importance, thus emphasizing multi-individual high-use areas. Contours representing various proportions of the whole probability surface were computed. The total area within each contour was then calculated.

Habitat use metrics were calculated by region as the mean of mean values for each track analyzed. Displacement was calculated as the straight line distance between release and furthest recorded locations. Straightness Index (SI) was calculated as the ratio of the straight line distance between the release location and last transmitted location over the total distance traveled between filtered points with a range of 0 (tortuous) to 1 (straight) (Batschelet 1981). All calculations took into account the curvature of the earth's surface. Sea surface temperature (SST) data from the NOAA/ NASA Advanced Very High Resolution Radiometer (AVHRR) Pathfinder product were merged at 0.05 degree, $8 \mathrm{~d}$ resolution to the satellite track data to calculate mean SST experienced by each turtle (www. nodc.noaa.gov/sog). Ocean surface chlorophyll a (chl a) pigment concentrations from the Sea-viewing Wide Field-of-view Sensor (SeaWiFS) were also merged at 0.1 degree, $8 \mathrm{~d}$ resolution with the satellite track data to calculate mean chl a concentrations experienced by each turtle (http://oceancolor.gsfc.nasa. gov/SeaWiFS). Individual turtle track durations, dis- placement from release location, average speed, and straightness of tracks were compared between habitats using independent $t$-tests (SYSTAT 2007).

Diet. During the course of standardized stranding surveys conducted from 2003 to 2007 along the $44.3 \mathrm{~km}$ Playa San Lázaro, Baja California Sur (Peckham et al. 2008), 88 loggerhead stomachs were collected for diet analysis. Stomachs were removed from the stranded turtles, transported to a field facility, and frozen as soon after collection as possible. Gross observations of stomach contents were made, and all contents including both hard and soft parts were sorted to the lowest identifiable taxon. Frequency of occurrence of major components was calculated by dividing the number of stomachs in which the prey item occurred by the total number of turtle stomachs examined. Stomach contents of turtles from the BCP were compared with those reported from juvenile turtles of the CNP, which were processed in the same way (Parker et al. 2005). Morisita's index was used to evaluate the similarity of observed diets from the 2 regions on a scale from 0 (no overlap) to 1 (complete overlap) (Horn 1966).

Relative energetics and habitat quality of alternative foraging strategies. To compare relative diet quality and energetic costs between habitats, we compared the movement rates of turtles, mean energy density of prey, and SST and chl a concentrations experienced by turtles in the 2 habitats. Dry weight energy densities $\left(\mathrm{kJ} \mathrm{g}^{-1}\right)$ were obtained from the literature for each species encountered or for the closest taxonomic order available. The mean value of the energy densities of all diet items present in more than $15 \%$ of stomachs was calculated as a measure of the relative energy quality of diets between regions. As ectotherms, the metabolic rate of loggerheads is strongly influenced by water temperature. Thus, we compared satellite-derived SST experienced by turtles as an index of thermal energetic costs between habitats. As proxies for primary production and, indirectly, prey abundance, we also compared satellite-derived chl a concentrations between the 2 habitats. Relative rates of primary production are well correlated with secondary productivity (Smith et al. 1986, Polovina et al. 2006, Gremillet et al. 2008). Chl a concentrations and SST experienced by each turtle were compared between habitats using independent $t$-tests (SYSTAT 2007). A Satterthwaite adjustment was used to address the large difference in variance in chl a concentrations between CNP oceanic and BCP neritic habitats. All averages are reported as mean $\pm \mathrm{SD}$.

Size distributions. Length frequency distributions were compared between turtles tracked from the CNP and BCP habitats in order to ascertain whether the observed difference in foraging strategy between regions was related to turtle size. Lengths reported as straight carapace length (SCL) were converted to 
curved carapace length (CCL) following the regression derived in Peckham et al. $\left(2008 ; \mathrm{N}=163, \mathrm{r}^{2}=0.93, \mathrm{p}<\right.$ $0.001)$ :

$$
\mathrm{SCL}=(0.932 \times \mathrm{CCL})+0.369
$$

Demographic analyses. To explore the possibility that variation in growth rate between juvenile strategies could affect overall population dynamics, we manipulated the demographic model used to make the 2001 NMFS-SEFSC loggerhead stock assessment (NMFS-SEFSC 2001). Because there is no specific parameter for growth rate in this stage-structured model, we lengthened the durations of the model's 2 'benthic juvenile' stages by $30 \%$, simulating the potential decrease in growth rate expected for turtles that do not recruit to neritic habitats (Snover 2002) in order to determine the resulting effect on lambda. To explore the possibility that reduced predation pressure may counteract the energetic disadvantages of oceanic foraging by juvenile turtles, we further manipulated the model to determine what proportional changes in survivorship would balance the decreased growth rates expected to result from juveniles remaining in oceanic habitats until reaching maturity. To do so we systematically changed the duration of the 2 'benthic juvenile' stages from 10 to $50 \%$ and calculated the corresponding change in survivorship of those stages required to maintain a constant value of lambda.

\section{RESULTS}

The UDs of turtles tracked from the BCP versus the CNP were widely divergent (Fig. 1). The number of days turtles were tracked from each region was not significantly different $(t=0.912, \mathrm{df}=61, \mathrm{p}=0.365)$. The 40 BCP juveniles spent the majority of the mean $144 \pm$ $98 \mathrm{~d}$ they were tracked in a geographically limited area on the continental shelf in the Bight of Ulloa, while the 23 CNP turtles ranged around the Central North Pacific during the mean $123 \pm 75$ d they were tracked. BCP tracked turtles were marginally larger than CNP tracked turtles $(71.4 \pm 6.9$ and $67.0 \pm 11.2 \mathrm{~cm}$, respectively; $t=1.951$, df $=61, \mathrm{p}<0.056$ ), but there was broad overlap in the length frequency of individuals tracked between regions (Table 1 ).

The UDs of the 40 turtles satellite tracked from the BCP were 2 orders of magnitude smaller across all UD

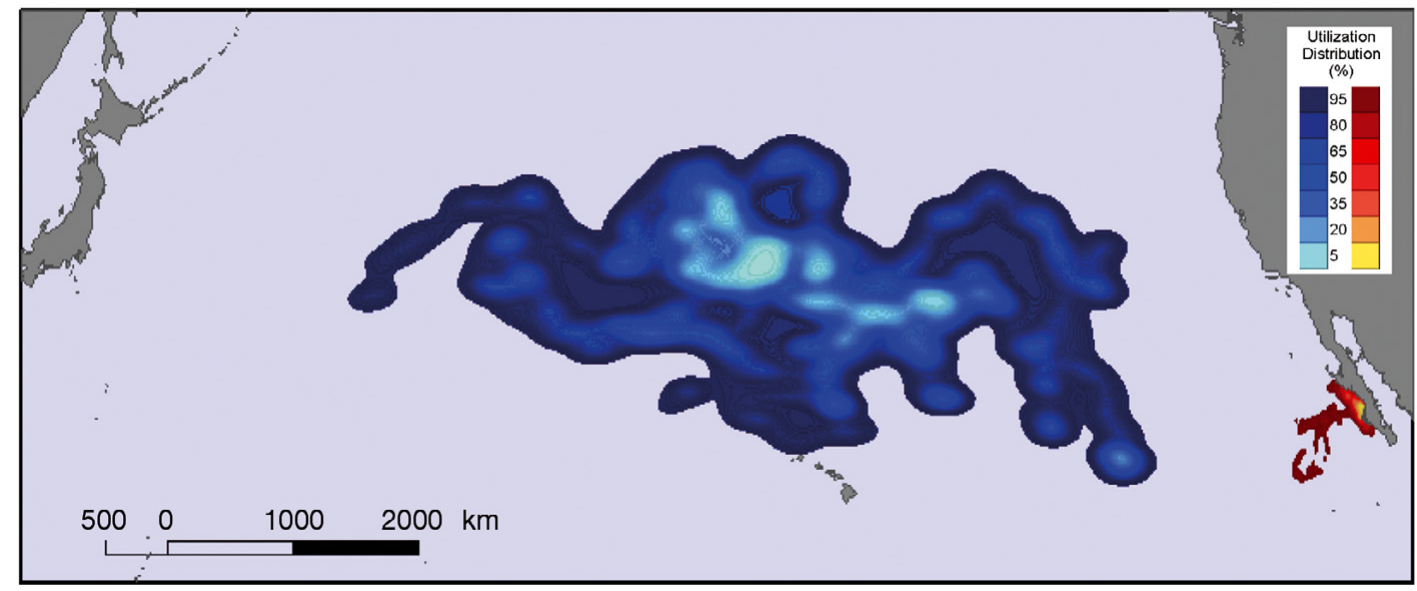

Fig. 1. Caretta caretta. Utilization distributions of juvenile turtles in the Central North Pacific (blue gradient) and at the Baja California Peninsula (red gradient)

Table 1. Caretta caretta. Habitat use metrics for turtles tracked via satellite telemetry from the Central North Pacific $(\mathrm{CNP}, \mathrm{N}=$ 23 turtles) and along the Baja California Peninsula (BCP, N = 40 turtles) (means of mean individual values). CCL: curved carpace length

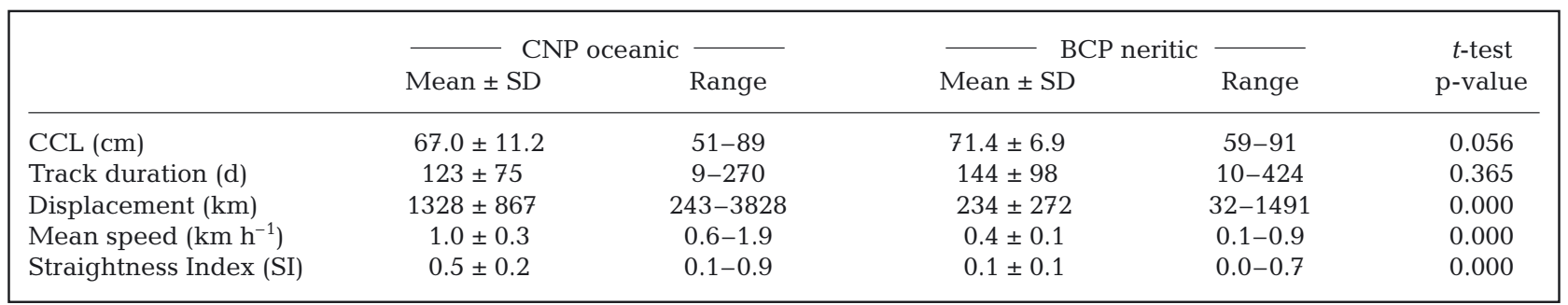


contours than those from the 23 individuals from the CNP (Figs. 1 \& 2). CNP turtles on average traveled much further per unit time (Fig. 3). The linear fit of median cumulative distance traveled per day for CNP turtles had a slope of 19.21 versus 9.44 for BCP turtles. CNP turtles displaced significantly further $(1328 \pm 867$ vs. $234 \pm$ $272 \mathrm{~km} ; t=-7.414, \mathrm{df}=61, \mathrm{p}<0.000)$, faster $(1.0 \pm 0.3 \mathrm{vs}$. $\left.0.4 \pm 0.1 \mathrm{~km} \mathrm{~h}^{-1} ; t=-10.259, \mathrm{df}=65, \mathrm{p}<0.000\right)$, and straighter (straightness index: $0.5 \pm 0.2$ vs. $0.1 \pm 0.1 ; t=$ 8.038, df $=61, \mathrm{p}<0.000$ ) than BCP turtles (Table 1).

Stomach contents of juvenile loggerheads in neritic habitats of the BCP differed from those in oceanic habitats of the CNP (Table 1) (Parker et al. 2005). Prey items present most frequently in the stomachs of BCP turtles were fish: searobins Prionotus spp. $(30 \%$ of stomachs), sand perches Diplectrum spp. (23\%), and lizardfish Synodus spp. (11\%), and crustaceans: pelagic red crabs Pleuroncodes planipes (14\%), Platymera gaudichaudii (6\%) and Hemisquilla ensigera (5\%). When present in stomachs of BCP turtles, fish and crustaceans were generally found in large quantities. The fish are all commonly caught and discarded as bycatch in local gillnets (S. H. Peckham unpubl. data). The most frequently occurring prey items in the stomachs of CNP turtles were pelagic gastropods: Janthina spp. (75\% of stomachs) and Carinaria cithara (50\%), and crustaceans that grow on loggerheads: hitchhiker crabs Planes spp. (56\%) and goose barnacles Lepas spp. (52\%). The pelagic gastropods were found in great quantities, but the crustaceans were found in very low quantities and so are unlikely to be important prey items for CNP turtles, although they were present

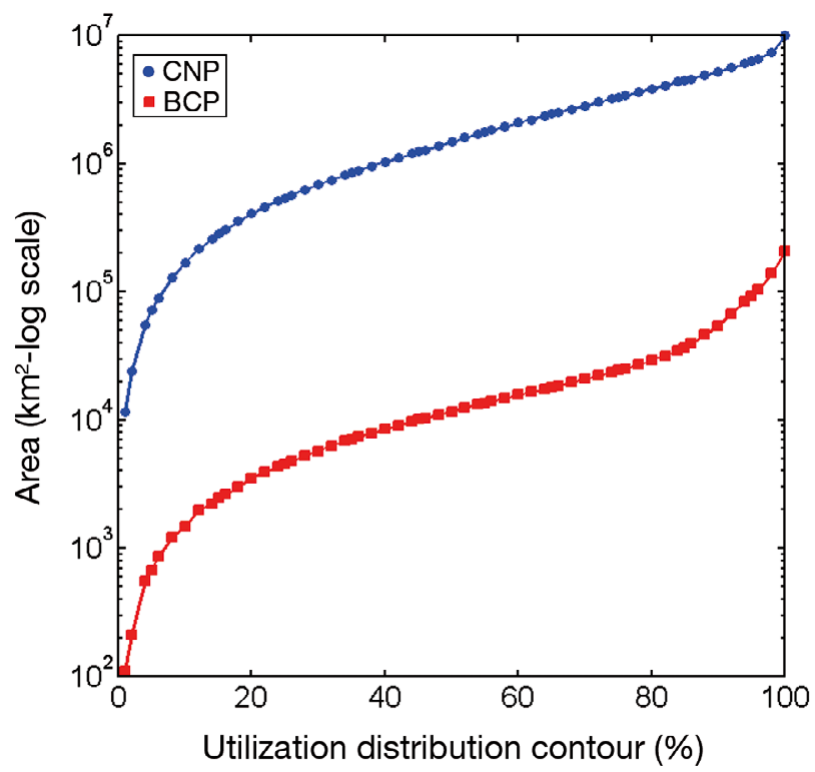

Fig. 2. Caretta caretta. Area of utilization distributions (UDs) of juvenile turtles at the Central North Pacific (CNP) and Baja California Peninsula (BCP). Area of UDs is 2 orders of magnitude larger for CNP juveniles across all UD contours

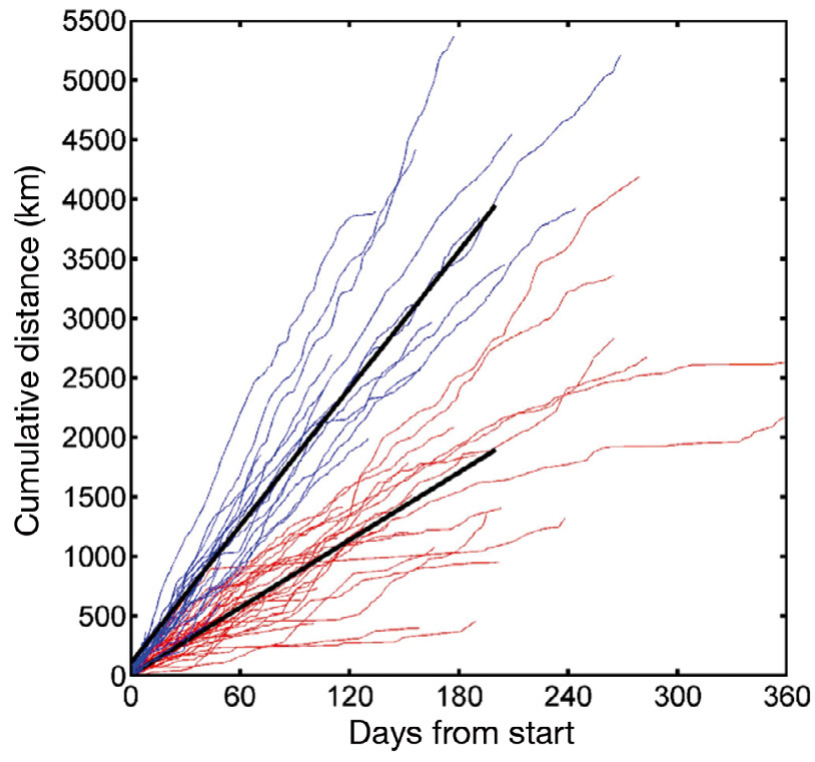

Fig. 3. Caretta caretta. Cumulative distance traveled by juvenile turtles satellite-tracked from Central North Pacific oceanic (blue; $\mathrm{N}=23$ ) and Baja California Peninsula neritic (red; $\mathrm{N}=40$ ) habitats. Thick lines represent linear fits of median values for each track by region

in a large proportion of stomachs. Salps and scyphozoans occurred relatively frequently (21 and 25\%, respectively). Similarity of prey species composition between the 2 regions was low (Morisita similarity index $=0.19$ ).

Juveniles foraging in BCP neritic habitats most likely enjoy an energetic advantage over those foraging in the oceanic CNP habitat. As reported above, within the BCP neritic habitat, turtles moved significantly slower (Table 1). The diet items of neritic foragers had a mean energy density of $18.1 \mathrm{~kJ} \mathrm{~g}^{-1}$, whereas the mean energy density of the diet items of oceanic foragers was $11.2 \mathrm{~kJ}$ $\mathrm{g}^{-1}$ (Table 2). Mean water temperatures experienced by turtles foraging in the CNP oceanic habitat $\left(19.7 \pm 1.8^{\circ} \mathrm{C}\right)$ were significantly cooler than those experienced in BCP neritic habitats $\left(24.0 \pm 1.9^{\circ} \mathrm{C} ;=8.884, \mathrm{df}=61, \mathrm{p}<0.000\right.$; Table 3). Mean of mean chl a concentrations experienced by turtles foraging in the CNP oceanic habitat $(0.131 \pm$ $0.038 \mathrm{mg} \mathrm{m}^{-3}$ ) were significantly lower than those experienced in BCP neritic habitats $\left(0.828 \pm 0.562 \mathrm{mg} \mathrm{m}^{-3}\right.$; $t=7.81, \mathrm{df}=39.8, \mathrm{p}<0.000$; Table 3 ). The variance in mean chl a concentrations experienced by BCP turtles (0.562) was an order of magnitude higher than that experienced by CNP turtles (0.038), but the minimum mean chl a concentration experienced by a BCP turtle $\left(0.192 \mathrm{mg} \mathrm{m}^{-3}\right)$ was greater than the maximum experienced by CNP turtles $\left(0.188 \mathrm{mg} \mathrm{m}^{-3}\right)$. Thus, all of the indices available in this study (prey quality, environmental productivity, movement, water temperature) suggest that BCP turtles enjoy a substantial energetic advantage 
Table 2. Caretta caretta. Percent occurrence of major prey items in turtle stomachs from the Baja California Peninsula ( $\mathrm{BCP}, \mathrm{N}=89$ stomachs) and the Central North Pacific (CNP, $N=52$; data from Parker et al. 2005). Energetic values (E, in $\mathrm{kJ} \mathrm{g}^{-1}$ dry weight) were obtained from the following sources: ${ }^{1}$ Castro-González et al. (1998); ${ }^{2}$ Castro-González et al. $(1995) ;{ }^{3}$ Chilton \& Bull $(1986) ;{ }^{4}$ Votier et al. (2004); ${ }^{5}$ Szaniawska \& Wolowicz (1986). Mean energetic values were calculated from all diet items occurring in $>15 \%$ of stomachs

\begin{tabular}{|lcccc|}
\hline Prey & CNP oceanic & $\mathrm{E}\left(\mathrm{kJ} \mathrm{g}^{-1}\right)$ & BCP neritic & $\mathrm{E}_{\left(\mathrm{kJ} \mathrm{g}^{-1}\right)}$ \\
\hline Fish & 7.7 & & 85.2 & $20.1^{1}$ \\
Decapods & 55.8 & $16.2^{2}$ & 31.8 & $16.2^{2}$ \\
Cephalopods & 21.2 & $20.7^{1}$ & 1.1 & \\
Pelagic gastropods & 75.0 & $15.2^{3}$ & 0.0 & \\
Barnacles (Lepas spp.) & 51.9 & $1.9^{4}$ & 0.0 & \\
Anthropogenic debris & 34.6 & 0.0 & 0.0 & \\
Scyphozoa (Velella velella) & 25.0 & $2.9^{1}$ & 0.0 & \\
Fish eggs & 25.0 & $24^{1}$ & 0.0 & \\
Pyrosoma & 21.0 & $4.9^{1}$ & 0.0 & \\
Amphipods & 46.2 & $15.1^{5}$ & 0.0 & \\
Mean prey quality (kJ $\left.\mathbf{~ ( k ) ~}^{-1}\right)$ & & $\mathbf{1 1 . 2}$ & & $\mathbf{1 8 . 2}$ \\
\hline
\end{tabular}

changes in survivorship required to maintain a constant value of lambda was linear (Fig. 4); relatively small changes in annual survivorship balanced larger changes in growth rate of larger juveniles. Specifically, based on our manipulation of the model the $30 \%$ increase in the durations of the 2 'benthic juvenile' stages expected for juveniles remaining in oceanic habitats would be counteracted in terms of lambda by a $1.85 \%$ increase in average survivorship.

\section{DISCUSSION}

Juvenile loggerhead turtles Caretta caretta of the North Pacific occur in one of at least 2 distinct habitats for

Table 3. Caretta caretta. Relative advantage of energetic factors (mean $\pm \mathrm{SD}$ ) for turtles at CNP oceanic versus BCP neritic foraging habitats: in all cases the neritic habitat has the energetic advantage

\begin{tabular}{|lcc|}
\hline & CNP oceanic & BCP neritic \\
\hline Prey abundance & Low & High \\
Prey quality $\left(\mathrm{kJ}^{-1}\right)$ & 11.2 & 18.2 \\
Movement rate $\left(\mathrm{km} \mathrm{h}^{-1}\right)$ & $1.0 \pm 0.3$ & $0.4 \pm 0.2$ \\
SST $\left({ }^{\circ} \mathrm{C}\right)$ & $19.7 \pm 1.8$ & $24.0 \pm 1.9$ \\
Chlorophyll $a\left(\mathrm{mg} \mathrm{m}^{-3}\right)$ & $0.131 \pm 0.038$ & $0.828 \pm 0.562$ \\
\hline
\end{tabular}

over CNP oceanic foraging juveniles (Table 3).

The length frequencies of loggerheads tracked from the CNP $(\mathrm{N}=23 ; 67.0 \pm 11.2 \mathrm{~cm} \mathrm{CCL})$ and the BCP $(\mathrm{N}=$ $40 ; 71.4 \pm 6.9 \mathrm{~cm}$ CCL) were not significantly different, but power to detect a difference was low (0.454). The 23 turtles captured from 1997 to 2000 in the CNP habitat were larger on average $(67.0 \pm 11.2 \mathrm{~cm}$ CCL; Table 1) than 63 loggerheads measured at BCS in 1999 $(62.0 \pm 13.0 \mathrm{~cm} \mathrm{CCL})$, though not significantly so $(t=$ -1.695, df = 84, p < 0.094) (Gardner \& Nichols 2001).

Manipulation of the 2001 NMFS-Southeast Fisheries Science Center loggerhead stock assessment model, based on parameters measured and estimated for the North Atlantic loggerhead population, suggest that differences in growth rates between the 2 juvenile strategies could impact lambda. When we lengthened the durations of the model's 2 'benthic juvenile' stages by $30 \%$ to simulate the potential decrease in growth rate for juveniles that forage in oceanic habitats relative to neritic habitats (Snover 2002), the model produced a decrease in lambda from 0.973 to 0.958 . With all other parameters held constant, the relationship between extended periods, the oceanic waters of the Central North Pacific (CNP) and the neritic waters of the Baja California Peninsula (BCP). The biological oceanography of these 2 habitats differs fundamentally in terms of temperature, productivity, and current regimes as well as the variability of each of these factors. The CNP oceanic habitat is characterized by lower primary production (0.01 to $1.00 \mathrm{mg} \mathrm{m}^{-3} \mathrm{chl} \mathrm{a}$ ), lower SST (5 to $26^{\circ} \mathrm{C}$ ), and strong seasonal variability relative to the BCP habitat (Polovina et al. 2001, Kobayashi et al. 2008). Juvenile loggerheads in the CNP are associated with the Transition Zone Chlorophyll Front (TZCF) and

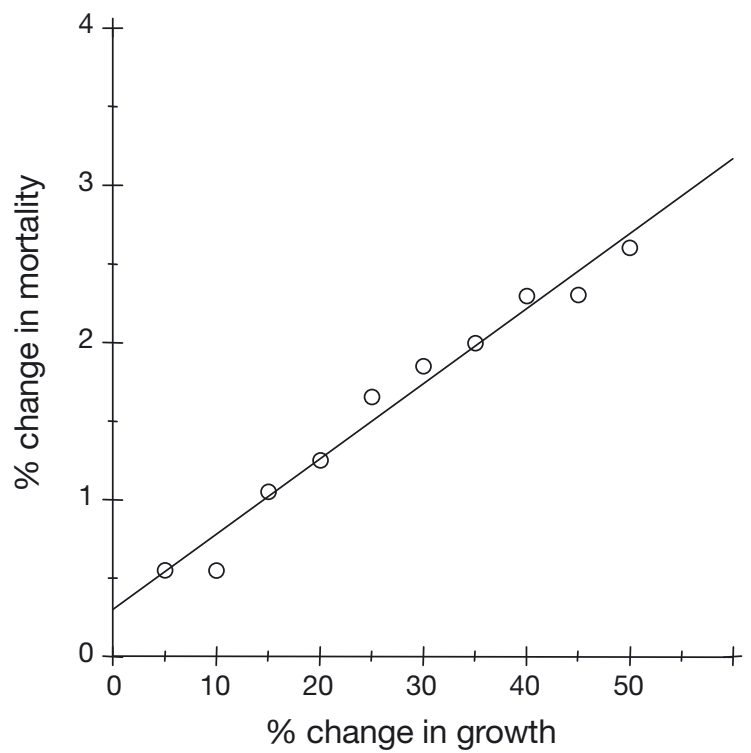

Fig. 4. Caretta caretta. Proportional change in juvenile mortality required to counteract proportional change in juvenile growth based on manipulation of the NMFS-SEFSC loggerhead stock assessment model 
the Kuroshio Extension Bifurcation Region (KEBR), dynamic mesoscale features characterized by elevated primary productivity (chl a concentrations of 0.11 to $0.31 \mathrm{mg} \mathrm{m}^{-3}$ ) (Polovina et al. 2000, 2001, 2004, 2006, Kobayashi et al. 2008) and associated secondary productivity (Polovina et al. 2006). Seasonally, the TZCF undergoes latitudinal shifts of $\sim 1000 \mathrm{~km}$ (Polovina et al. 2001, 2004), forcing oceanic predators such as loggerhead turtles to undertake seasonal migrations in order to take advantage of TZCF productivity (Polovina et al. 2001, 2004). In addition, loggerheads must negotiate strong surface currents associated with the features such as the prevailing easterly geostrophic currents of 0.15 to $0.24 \mathrm{~km} \mathrm{~h}^{-1}$ (Polovina et al. 2004).

In contrast, the BCP neritic habitat occupied by loggerheads is located at the southern end of the highly productive California Current and characterized by year-round coastal upwelling conditions with mesoscale eddies, and fronts with seasonally variable SSTs (15 to $26^{\circ} \mathrm{C}$ ), and high chl a concentrations (0.2 to $19.0 \mathrm{mg} \mathrm{m}^{-3}$ ) (Espinosa-Carreon et al. 2004, Legaard \& Thomas 2006, Gonzalez-Rodriguez 2008). Generally, primary production in the region remains high relative to the rest of the Pacific Ocean, with chl a concentrations rarely dropping below $1.0 \mathrm{mg} \mathrm{m}^{-3}$, and surface currents are weak and variable in direction (EspinosaCarreon et al. 2004, Legaard \& Thomas 2006, Gonzalez-Rodriguez 2008). In summary, juveniles foraging at $\mathrm{BCP}$ neritic habitats probably enjoy an energetic advantage by moving less distance through water of metabolically more favorable temperature in which they consume higher quality, more abundant prey.

The aforementioned differences in the biological oceanography of the 2 habitats result in proximal differences in turtle movement and diet. While the number of locations as well as location accuracy can influence estimates of speed and home range in satellite tracking data (Bradshaw et al. 2007), the difference in movement statistics between habitat type that we found was so large that it was certainly not an artifact. CNP turtles moved 2 orders of magnitude further and twice as fast in comparison with BCP loggerheads, presumably in order to track prey associated with the higher productivity of the TZCF and KEBR (Polovina et al. 2001, 2006, Kobayashi et al. 2008). Concentrations of chl a experienced by CNP turtles in this study were considerably higher than if they had remained in any one area of the CNP as small as that utilized by BCP turtles. In contrast, as a result of the higher overall primary productivity of the BCP neritic habitat, turtles foraging there experienced significantly higher concentrations of chl a while moving significantly less.

Divergence in the UDs of turtles tracked from the BCP versus the CNP most likely reflects fundamental differences in the distribution, abundance, and quality of prey between the 2 regions. The consistently higher primary productivity of the BCP neritic habitat likely translates into higher prey abundance for foraging loggerheads. Demersal fish and red crabs are abundant in the BCP neritic habitat, with red crabs present year-round at high densities (20 to 30 tons $\mathrm{km}^{-2}$ ) (Aurioles-Gamboa 1995). Furthermore, small-scale fisheries are ubiquitous at the $\mathrm{BCP}$, offering loggerheads discarded fish in high abundance (Peckham et al. 2008). In contrast, the TZCF habitat has lower primary production and productivity is generally patchy and ephemeral (Polovina et al. 2004, Parker et al. 2005, Kobayashi et al. 2008).

The crustacean prey of BCP turtles is consistent with diet studies of loggerheads from other neritic habitats (Plotkin et al. 1993, Limpus \& Limpus 2003). However, pelagic red crabs occurred at lower frequencies and fish occurred at higher frequencies compared with previous studies with considerably smaller sample sizes (Ramirez-Cruz et al. 1991, Nichols 2003). Loggerheads are opportunistic, generalist foragers and are known to consume fish as fisheries discards and directly from fishing gear (Shoop \& Ruckdeschel 1982, Tomas et al. 2001). The fish species retrieved from stomachs in this study were demersal predators of no commercial value that are frequently caught and discarded by local gillnetters (J. Lucero-Romero pers. comm.). We commonly observed carcasses of Prionotus spp., Diplectrum spp., and Synodus spp. floating in the BCP loggerhead high use area, and loggerheads were observed consuming these fish as both discards and directly from fishing gear (S. H. Peckham unpubl. data). Thus, our stomach content data and informal observations indicate that fisheries discards and bycatch form an important part of their diet at the BCP. It is likely that this behavior exposes BCP loggerheads to extremely high levels of incidental mortality in local small-scale fisheries.

Because quantitative diet data were not available, our assessment of the relative energy density between habitats was necessarily qualitative. Our approach probably overestimates the actual energy density for CNP oceanic foragers because high energy density items such as decapods, fish eggs, and cephalopods were found in low quantities, though present in 20 to $50 \%$ of stomachs (Parker et al. 2005). Furthermore, salps and scyphozoans (of relatively low energy density) are underestimated in loggerhead diet studies because they are digested quickly, leaving no identifiable remains (Plotkin et al. 1993). However, leatherback turtles Dermochelys coriacea and fish selectively feed on and may selectively assimilate gonads and other tissues, which are known to be of higher energy content than whole salps and scyphozoans (Kashkina 1987, Davenport \& Balazs 1991, Doyle et al. 2007). Loggerheads may also be capable of this selectivity with respect to salps and scyphozoans, and this would increase slightly the relative energy 
density on CNP loggerhead diet. Nonetheless, based on optimal foraging theory, by which predators should maximize their intake of high quality prey (Stephens \& Krebs 1986), the prevalence and diversity of low energetic quality prey in the diet of oceanic juveniles suggest that the higher quality prey consumed by neritic foragers are less accessible or nonexistent in the CNP oceanic habitat. However, BCP loggerheads likely incurred higher energetic costs associated with diving to acquire their neritic prey relative to CNP juveniles foraging on neustonic prey at the sea surface.

While CNP juvenile loggerheads had to travel greater distances and at higher speeds to fulfill their nutritional requirements, movements of oceanic species can also be influenced by current patterns (Gaspar et al. 2006). Overall geostrophic currents were similar in velocity between the 2 regions ( 0.0 to $0.7 \mathrm{~km} \mathrm{~h}^{-1}$ ) (Polovina et al. 2004, Gonzalez-Rodriguez 2008), although Polovina et al. $(2000,2006)$ found that CNP turtles actively swim against dominant westward flowing geostrophic currents of 0.15 to $0.24 \mathrm{~km} \mathrm{~h}^{-1}$, which results in a $50 \%$ reduction in their net westward displacement and suggests that CNP turtles expend considerably more energy in swimming than indicated by the travel rates observed here. In contrast, the oceanography of the BCP shelf area is dominated by meanders, eddies, and filaments that result in variable direction of surface currents (EspinosaCarreon et al. 2004, Gonzalez-Rodriguez 2008). These currents in turn cause retention of nutrients, phytoplankton, and zooplankton, including pelagic red crabs (Aurioles-Gamboa 1992, Lavaniegos 1994, GonzalezRodriguez 2008). Thus, juvenile turtles foraging in the $\mathrm{BCP}$ region could be 'retained' along with their pelagic red crab prey, resulting in reduced energy expended against geostrophic currents in comparison with CNP turtles. In fact, the observed tortuous and circumscribed tracks of turtles at the BCP could result from relatively passive transport of turtles by local currents, suggesting that the observed mean travel rate for BCP turtles could represent some degree of passive transport rather than active swimming and could therefore be an overestimate of energy expenditure by BCP turtles.

Differences in dive behavior may also affect energy expenditure. Howell et al. (2010) reported that CNP juvenile loggerheads spent over $80 \%$ of their time within $5 \mathrm{~m}$ of the surface, presumably reflecting their consumption of neustonic prey. Comprehensive dive data have not been collected for loggerheads at BCP, but diet composition suggests that they can forage on or near the benthos. If juveniles at BCP spend greater proportions of their foraging time at depth, they may incur higher energetic costs associated with diving relative to juveniles in the CNP.

Field studies of the effects of water temperature on energy budgets of juvenile loggerheads have not been conducted (Wallace \& Jones 2008). The higher water temperatures experienced by turtles at $\mathrm{BCP}$ neritic habitats may confer higher metabolic rates (Lutz et al. 1989, Hochscheid et al. 2004). But higher water temperature also confers better energy assimilation for ectotherms including enhanced prey detection, prey capture, ingestion, digestion, and absorption of food (Congdon 1989, Dunham et al. 1989). Higher water temperatures are reported to be energetically favorable for sea turtles, as long as they do not approach upper thermal limits (Bjorndal 1980). Thus, the higher water temperatures experienced by turtles foraging at $\mathrm{BCP}$ habitats may augment the energetic advantage by increasing food processing and assimilation efficiencies, although this may come at a cost of increased basal metabolic rate.

\section{Alternative foraging strategies}

Foraging plasticity associated with habitat choice has been found in a variety of marine turtles, including leatherbacks (Hays et al. 2004) and green turtles (Hays et al. 2002, Reich et al. 2007). Loggerheads take advantage of both oceanic and neritic habitats as both juveniles (Bolten 2003, McClellan \& Read 2007) and adults (Hatase et al. 2002, 2007, Hawkes et al. 2006). Thus, it is not surprising that juvenile loggerheads in the North Pacific use different habitats and employ different foraging strategies in doing so.

As such, 2 hypotheses could account for the use of the 2 different regions of the North Pacific by juvenile loggerheads: (1) an ontogenetic habitat shift, or (2) alternative foraging strategies. It is unlikely that the pattern we have documented reflects an ontogenetic shift for 2 reasons: (1) if an ontogenetic shift occurs from CNP oceanic to BCP neritic habitats, a clear segregation in size frequencies would be expected between the 2 habitats, as has been demonstrated from the Atlantic (Bolten 2003). However, turtles tracked in the CNP and the BCP were not significantly different in size (Table 1). Thus, the most likely explanation for the use of these 2 habitats is that they represent alternative foraging strategies for North Pacific juvenile loggerheads with juveniles remaining in either the oceanic or neritic habitats for extended periods, perhaps until reaching maturity; (2) fewer than 10 of more than 150 juveniles captured and tracked to date from the CNP (Polovina et al. 2000, 2004) or captive-reared and released from Japan (Polovina et al. 2006) moved towards neritic habitats of either Mexico or Japan. Instead, juveniles tracked from the CNP actively maintained their positions in the oceanic habitats of the CNP, leading Polovina et al. (2006) to conclude that 'a significant number of juveniles use pelagic habitat for 
their entire juvenile phase.' Furthermore, none of the 40 turtles tracked from the neritic habitats of the BCP moved to occupy the oceanic habitats of the CNP, although 5 individuals migrated to or towards Japan, well south of the CNP foraging area (Nichols et al. 2000, Nichols 2003, Peckham et al. 2007). Thus, we found that North Pacific loggerheads have at least 2 distinct, non-overlapping foraging habitats.

\section{Alternative life history strategies?}

Given the apparent energetic advantages of neritic foraging (Table 3), extended residence by juvenile loggerheads in neritic versus oceanic habitats is likely to produce differential vital rates including growth, age and size at maturity, fecundity, and survivorship. Age and size at maturity are strongly influenced by growth rates and are fundamentally important life history traits due to their effects on fecundity and survival (Stearns 1996). Growth rates are highly variable in reptiles and other taxa, due in part to resource limitation (Caswell 1983). Loggerhead turtle growth rates are highly variable across their range, and these differences have been attributed to several factors including quality and quantity of prey as well as foraging habitat (Van Buskirk \& Crowder 1994, Klinger \& Musick 1995, Zug et al. 1995, Bjorndal et al. 2003). Snover (2002) found that juvenile loggerheads grew up to $30 \%$ faster upon shifting to neritic from oceanic habitats in the Northwest Atlantic, suggesting potential life history advantages for juveniles that forage neritically, a phenomenon apparently borne out in Japanese first-time nesters in which neritic foragers are significantly larger than oceanic foragers (Hatase et al 2010). Similarly, the energetic advantages enjoyed by juveniles foraging at BCP neritic habitats likely enable them to achieve higher growth rates than those foraging in CNP oceanic habitats.

\section{Demographic implications}

All else remaining equal, neritic foraging would seem to be the far better strategy for juvenile loggerheads. But how then could an oceanic juvenile strategy with potentially slower growth rates and later maturity, plus potential associated effects including smaller adult size and lower fecundity (or some combination of these), be maintained? Juveniles maximize their fitness by increasing their probability of survival to reproduction through a balance of optimizing growth rates and minimizing predation risk (Werner \& Gilliam 1984, Mangel \& Clark 1986). In many cases, there are trade-offs in which habitats that afford higher growth rates come with higher predation risk (Lima \& Dill
1990). Higher predation rates in neritic habitats have been assumed to cause smaller juvenile loggerheads to forego the advantages of neritic foraging until they are large enough to avoid predation (Carr 1987, Snover 2002, Bolten 2003). Predation risk of sharks limits the use of high quality foraging areas by sea turtles in habitats with intact predator communities (Heithaus et al. 2007), and higher predation rates have been observed in juvenile loggerheads newly arrived to neritic habitats in Australia relative to larger adults (Limpus \& Limpus 2003).

Despite the impression that neritic foraging would be the far better strategy for juvenile loggerheads, the results of our modeling show that the large disadvantage in growth rate expected from the energetically poor oceanic strategy could be offset by only small advantages in survivorship associated with lower predation rates in the oceanic habitat. Our finding is consistent with life history studies showing that survivorship has much higher elasticity than other vital rates across taxa with delayed maturity (Heppell et al. 1999). More extreme alternatives in life history strategies persist in populations of salmon and other taxa (Gross 1985); though perhaps counterintuitive, our results explaining the persistence of 2 foraging strategies with large differences in resulting energetics should not be surprising.

Our modeling should be interpreted with caution because the parameters of the model were derived from or estimated for the North Atlantic loggerhead population. Assorted life history parameters are known to differ between Atlantic and Pacific populations of loggerheads and other turtles (Van Buskirk \& Crowder 1994, Wallace et al. 2006), and these differences could affect the magnitude of the effects examined here. Also, our manipulation of the model examined the effects of growth rate on stage duration, but did not factor in the additional advantages to higher growth rates including size at maturity and resulting higher reproductive output expected from neritic foraging. Incorporating the advantages in reproductive output associated with neritic foraging into the model would clearly increase the margin of survivorship advantage required to justify the oceanic strategy.

\section{Conservation implications}

Bycatch of juvenile loggerheads was high at the CNP oceanic habitat in high-seas driftnets until they were banned in 1992 (Wetherall et al. 1993), and bycatch likely continues to be high in high-seas longlines (Lewison et al. 2004). However, bycatch is currently considerably higher in the $\mathrm{BCP}$ neritic habitats due to small-scale fisheries (Peckham et al. 2007, 2008). If 
$\mathrm{BCP}$ neritic foraging juveniles realize higher growth rates, size and age at maturity and fecundity (or any one of these), they could have higher reproductive potential and therefore a greater per turtle potential contribution to lambda and population recovery. The question remains as to how growth and survivorship actually vary between the 2 habitats and what is the relative contribution of animals in these 2 environments to the overall population trajectory of loggerheads in the North Pacific Ocean. The higher potential growth and fecundity and the high bycatch mortality rate together imply that conservation efforts directed at mitigating or even eliminating bycatch at the $\mathrm{BCP}$ loggerhead foraging high-use area could offer considerable demographic leverage towards recovery of the overall population.

\section{CONCLUSIONS}

The fate of juvenile life history stages in sea turtles is an important determinant of population change (Crouse et al. 1987, Crowder et al. 1994). As demonstrated here, the interaction of decades-long juvenile stages with ranges that span fundamentally different habitats may produce divergent life history strategies between juveniles of the same population. To evaluate the importance of these alternative life history strategies to population growth in loggerhead turtles, we need to determine juveniles' fidelity to oceanic or neritic habitats and how long they inhabit them. Considered more broadly, our findings suggest that the ecologies of juveniles of other marine megafauna with delayed reproduction may play important roles in determining their population dynamics. Elucidating the juvenile ecologies of marine megafauna is important for understanding their ecology and guiding their management.

Acknowledgements. We thank our fisher partners of Puerto López Mateos and other Pacific BCS communities for their trust and partnership. We are very grateful to V. de la TobaVallalolid, A. Gaos, J. Lucero, R. Rangel, J. Romero, N. Rossi, E. Caballero, V. Cordi, E. Flores, R. Donadi, D. Wingfield and D. Parker plus many others of Equipo ProCaguama and the Grupo Tortuguero for field assistance. We thank J. Seminoff and T. Tinker for counsel and modeling advice plus D. Costa and B. Block an the TOPP team for their support of the satellite telemetry. J. Estes, D. Croll, L. Crowder, B. Wallace, and 2 anonymous reviewers improved the manuscript with helpful critiques. Research was authorized by the Mexican government through SEMARNAP and SEMARNAT permits 150496213-03, 280597-213-03， 190698-213-03， 280499-213-03, 280700-213-03, SGPA/DGVS/002 4661, SGPA/DGVS/10358, and SGPA/DGVS/03501/06. Animal handling was in full compliance with CARC/IACUC protocol at UC Santa Cruz. This work was supported by the David and Lucile Packard Foundation, NOAA Fisheries, Western Pacific Regional Fisheries Management Council, Project GLOBAL, PADI Founda- tion, T\&E Foundation, Wallace Research Foundation, School for Field Studies, Earthwatch Institute, ONR/National Oceanographic Partnership Program, Wildcoast, Blue Ocean Institute, and ProPeninsula. S.H.P. was supported with CILSNSF, Project Global and UCMEXUS fellowships and awards.

\section{LITERATURE CITED}

Aurioles-Gamboa D (1992) Inshore-offshore movements of pelagic red crabs Pleuroncodes planipes (Decapoda, Anomura, Galatheidae) off the Pacific coast of Baja-CaliforniaSur, Mexico. Crustaceana 62:71-84

Aurioles-Gamboa D (1995) Distribucion y abundancia de la langostilla bentonica (Pleuroncodes planipes) en la plataforma continental de la costa oeste de la Baja California peninsula. In: Aurioles-Gamboa D, Balart EF (eds) La Langostilla: biología, ecología, y aprovechamiento. CIBNOR, La Paz, p 59-78

Balazs G, Miya RK, Beavers SC (1996) Procedures to attach a satellite transmitter to the carapace of an adult green turtle, Chelonia mydas. In: Keinath JA, Barnard DE, Musick JA, Bell BA (eds) Fifteenth Annual Symposium on Sea Turtle Biology and Conservation. NOAA, NMFS, United States Department of Commerce, Washington, DC, p 21-26

Batschelet E (1981) Circular statistics in biology. Academic Press, New York, NY

Baum JK, Myers RA, Kehler DG, Worm B, Harley SJ, Doherty PA (2003) Collapse and conservation of shark populations in the Northwest Atlantic. Science 299:389-392

Bjorndal KA (1980) Nutrition and grazing behavior of the green turtle Chelonia mydas. Mar Biol 56:147-154

Bjorndal KA, Bolten AB, Martins HR (2000) Somatic growth model of juvenile loggerhead sea turtles Caretta caretta: duration of pelagic stage. Mar Ecol Prog Ser 202:265-272

Bjorndal KA, Bolten AB, Dellinger T, Delgado C, Martins HR (2003) Compensatory growth in oceanic loggerhead sea turtles: response to a stochastic environment. Ecology 84:1237-1249

Bolnick DI, Svanback R, Fordyce JA, Yang LH, Davis JM, Hulsey CD, Forister ML (2003) The ecology of individuals: incidence and implications of individual specialization. Am Nat 161:1-28

Bolten AB (2003) Active swimmers - passive drifters: the oceanic juvenile stage of loggerheads in the Atlantic system. In: Bolten AB, Witherington B (eds) Loggerhead sea turtles. Smithsonian Books, Washington, DC, p 63-78

> Bradshaw CJA, Sims DW, Hays GC (2007) Measurement error causes scale-dependent threshold erosion of biological signals in animal movement data. Ecol Appl 17: 628-638

Broderick AC, Glen F, Godley BJ, Hays GC (2003) Variation in reproductive output of marine turtles. J Exp Mar Biol Ecol 288:95-109

Carr A (1987) New perspectives on the pelagic stage of sea turtles. Conserv Biol 1:103-121

Carr A, Goodman D (1970) Ecological implications of size and growth in Chelonia. Copeia 1970:783-786

Castro-González MA, Carillo-Dominquez S, Perez-Gil F, Calvo-Carillo C (1995) Composición quimica de la langostilla. In: Aurioles-Gamboa D, Balart EF (eds) La langostilla: biología, ecologia, y aprovechamiento. CIBNOR, La Paz, p 163-178

Castro-González MA, Silencio-Barrita JL, Juarez-Silva ME, Montaño-Benavides S, Perez-Gil F (1998) Composición química de la fauna de acompañamiento del camarón de Veracruz (Golfo de México). Rev Biol Trop 46:249-256

Caswell H (1983) Phenotypic plasticity in life-history traits demographic effects and evolutionary consequences. Am 
Zool 23:35-46

Chilton NB, Bull CM (1986) Size-related selection of two intertidal gastropods by the reef crab Ozius truncatus. Mar Biol 93:475-480

Congdon JD (1989) Proximate and evolutionary constraints on energy relations of reptiles. Physiol Zool 62:356-373

Crouse DT (1999) The consequences of delayed maturity in a human-dominated world. In: Musick JA (ed) Life in the slow lane: ecology and conservation of long-lived marine animals. Am Fisheries Soc Symp 23, Bethesda, MD, p 195-202

Crouse DT, Crowder LB, Caswell H (1987) A stage-based population-model for loggerhead sea-turtles and implications for conservation. Ecology 68:1412-1423

Crowder LB, Crouse DT, Heppell SS, Martin TH (1994) Predicting the impact of turtle excluder devices on loggerhead sea-turtle populations. Ecol Appl 4:437-445

Davenport J, Balazs GH (1991) 'Fiery Bodies' — Are pyrosomas an important component of the diet of leatherback turtles? Br Herpetol Soc Bull 37:33-38

> Doyle TK, Houghton JDR, McDevitt R, Davenport J, Hays GC (2007) The energy density of jellyfish: estimates from bomb-calorimetry and proximate-composition. J Exp Mar Biol Ecol 343:239-252

Dunham AE, Grant BW, Overall KL (1989) Interfaces between biophysical and physiological ecology and the population ecology of terrestrial vertebrate ectotherms. Physiol Zool 62:335-355

Espinosa-Carreon TL, Strub PT, Beier E, Ocampo-Torres F, Gaxiola-Castro G (2004) Seasonal and interannual variability of satellite-derived chlorophyll pigment, surface height, and temperature off Baja California. J Geophys Res 109: C03039, doi:10.1029/2003JC002105

- Frazer NB, Richardson JI (1986) The relationship of clutch size and frequency to body size in loggerhead turtles, Caretta caretta. J Herpetol 20:81-84

Gardner SC, Nichols WJ (2001) Assessment of sea turtle mortality rates in the Bahía Magdalena region, Baja California Sur, México. Chelonian Conserv Biol 4:197-199

> Gaspar P, Georges JY, Fossette S, Lenoble A, Ferraroli S, Le Maho Y (2006) Marine animal behaviour: neglecting ocean currents can lead us up the wrong track. Proc Biol Sci 273:2697-2702

Gonzalez-Rodriguez E (2008) Variabilidad de la productividas primaria en el Golfo de Ulloa, costa occidental de Baja California Sur. Ciencias Marinas, La Paz

> Gremillet D, Lewis S, Drapeau L, van der Lingen CD and others (2008) Spatial match-mismatch in the Benguela upwelling zone: Should we expect chlorophyll and seasurface temperature to predict marine predator distributions? J Appl Ecol 45:610-621

Gross MR (1985) Disruptive selection for alternative life histories in salmon. Nature 313:47-48

Hatase H, Takai N, Matsuzawa Y, Sakamoto W and others (2002) Size-related differences in feeding habitat use of adult female loggerhead turtles Caretta caretta around Japan determined by stable isotope analyses and satellite telemetry. Mar Ecol Prog Ser 233:273-281

> Hatase H, Omuta K, Tsukamoto K (2007) Bottom or midwater: alternative foraging behaviours in adult female loggerhead sea turtles. J Zool 273:46-55

Hatase H, Omuta K, Tsukamoto K (2010) Oceanic residents, neritic migrants: a possible mechanism underlying foraging dichotomy in adult female loggerhead turtles (Caretta caretta). Mar Biol 157:1337-1342

> Hawkes LA, Broderick AC, Coyne MS, Godfrey MH and others (2006) Phenotypically linked dichotomy in sea turtle foraging requires multiple conservation approaches. Curr Biol 16:990-995
Hawkes LA, Broderick AC, Coyne MS, Godfrey MH, Godley BJ (2007) Only some like it hot - quantifying the environmental niche of the loggerhead sea turtle. Divers Distrib 13:447-457

Hays GC, Glen F, Broderick AC, Godley BJ, Metcalfe JD (2002) Behavioural plasticity in a large marine herbivore: contrasting patterns of depth utilisation between two green turtle (Chelonia mydas) populations. Mar Biol 141: 985-990

> Hays GC, Houghton JDR, Isaacs C, King RS, Lloyd C, Lovell P (2004) First records of oceanic dive profiles for leatherback turtles, Dermochelys coriacea, indicate behavioural plasticity associated with long-distance migration. Anim Behav 67:733-743

Heithaus MR, Frid A, Wirsing AJ, Dill LM and others (2007) State-dependent risk-taking by green sea turtles mediates top-down effects of tiger shark intimidation in a marine ecosystem. J Anim Ecol 76:837-844

Heppell SS, Crowder LB, Menzel TR (1999) Life table analysis of long-lived marine species, with implications for conservation and management. In: Musick JA (ed) Life in the slow lane: ecology and conservation of long-lived marine animals. Am Fisheries Soc Symp 23, Bethesda, MD, p 137-148

Heppell SS, Crowder LB, Crouse DT, Epperly S, Frazer NB (2003) Population models for Atlantic loggerheads: past, present, and future. In: Bolten $\mathrm{AB}$, Witherington $\mathrm{B}$ (eds) Loggerhead sea turtles. Smithsonian, Washington, DC, p 255-273

Hochscheid S, Bentivegna F, Speakman JR (2004) Long-term cold acclimation leads to high $\mathrm{Q}_{10}$ effects on oxygen consumption of loggerhead sea turtles Caretta caretta. Physiol Biochem Zool 77:209-222

> Horn HS (1966) Measurement of 'overlap' in comparative ecological studies. Am Nat 100:419-424

- Howell EA, Kobayashi DR, Parker DM, Balazs GH, Polovina JJ (2008) TurtleWatch: a tool to aid in the bycatch reduction of loggerhead turtles Caretta caretta in the Hawaii-based pelagic longline fishery. Endang Species Res 5: 267-278

> Howell E, Dutton P, Polovina J, Bailey H, Parker D, Balazs G (2010) Oceanographic influences on the dive behavior of juvenile loggerhead turtles (Caretta caretta) in the North Pacific Ocean. Mar Biol 157:1011-1026

Kashkina AA (1987) Feeding on salps (Tunicata) of fishes. Vopr Ikhtiol 3:440-447

- Klinger RC, Musick JA (1995) Age and growth of loggerhead turtles (Caretta caretta) from Chesapeake Bay. Copeia 204-209

Kobayashi DR, Polovina J, Parker D, Kamezaki N and others (2008) Pelagic habitat characterization of loggerhead sea turtles, Caretta caretta, in the North Pacific Ocean (19972006): insights from satellite tag tracking and remotely sensed data. J Exp Mar Biol Ecol 356:96-114

Lavaniegos BE (1994) Dispersion and development patterns in larvae of Nyctiphanes simplex (Euphausiacea) in the upwelling region off Baja California. Mar Ecol Prog Ser 106:207-225

- Legaard KR, Thomas AC (2006) Spatial patterns in seasonal and interannual variability of chlorophyll and sea surface temperature in the California Current. J Geophys Res 111: C06032, doi:10.1029/2005JC003282

Lewison RL, Crowder LB, Read AJ, Freeman SA (2004) Understanding impacts of fisheries bycatch on marine megafauna. Trends Ecol Evol 19:598-604

> Lima SL, Dill LM (1990) Behavioral decisions made under the risk of predation - a review and prospectus. Can J Zool 68:619-640

Limpus CJ, Limpus DJ (2003) Biology of the loggerhead turtle in western south pacific foraging areas. In: Bolten $A B$, 
Witherington B (eds) Loggerhead sea turtles. Smithsonian Books, Washington, DC, p 93-113

Lutz PL, Bergey ANN, Bergey M (1989) Effects of temperature on gas exchange and acid-base balance in the sea turtle Caretta caretta at rest and during routine activity. J Exp Biol 144:155-169

- Mangel M, Clark CW (1986) Towards a unified foraging theory. Ecology 67:1127-1138

- Mansfield KL, Saba VS, Keinath JA, Musick JA (2009) Satellite tracking reveals a dichotomy in migration strategies among juvenile loggerhead turtles in the Northwest Atlantic. Mar Biol 156:2555-2570

McClellan CM, Read AJ (2007) Complexity and variation in loggerhead sea turtle life history. Biol Lett 3:592-594

McClellan CM, Braun-McNeill J, Avens L, Wallace BP, Read AJ (2010) Stable isotopes confirm a foraging dichotomy in juvenile loggerhead sea turtles. J Exp Mar Biol Ecol 387: 44-51

Nichols WJ (2003) Biology and conservation of sea turtles in Baja California, Mexico. PhD dissertation, School of Renewable Resources, University of Arizona, Tucson, AZ

Nichols WJ, Resendiz A, Seminoff JA, Resendiz B (2000) Transpacific migration of a loggerhead turtle monitored by satellite telemetry. Bull Mar Sci 67:937-947

NMFS-SEFSC (2001) Stock assessments of loggerhead and leatherback sea turtles. US Dept of Commerce NOAA Tech Memo NMFS/SEFSC-455. US Department of Commerce, NOAA-NMFS-Southeast Fisheries Science Center, Miami, FL

Palacios DM, Bograd SJ, Foley DG, Schwing FB (2006) Oceanographic characteristics of biological hot spots in the North Pacific: a remote sensing perspective. Deep-Sea Res II 53:250-269

Parker DM, Cooke WJ, Balazs GH (2005) Diet of oceanic loggerhead sea turtles (Caretta caretta) in the central North Pacific. Fish Bull 103:142-152

Peckham SH, Maldonado-Diaz D, Walli A, Ruiz G, Nichols WJ, Crowder LB (2007) Small-scale fisheries bycatch jeopardizes endangered Pacific loggerhead turtles. PLoS ONE 2:e1041

Peckham SH, Maldonado-Diaz D, Koch V, Mancini A, Gaos A, Tinker MT, Nichols WJ (2008) High mortality of loggerhead turtles due to bycatch, human consumption and strandings at Baja California Sur, Mexico, 2003 to 2007. Endang Species Res 5:171-183

Pitman RL (1990) Pelagic distribution and biology of sea turtles in the eastern tropical Pacific. In: Richardson EH, Richardson JA, Donnelly M (eds) Proc Tenth Annual Workshop on Sea Turtles Biology and Conservation. NOAA Tech Memo NMFS-SEC-278. US Department of Commerce, Washington, DC, p 143-148

Plotkin PT, Wicksten MK, Amos AF (1993) Feeding ecology of the loggerhead sea-turtle Caretta caretta in the Northwestern Gulf of Mexico. Mar Biol 115:1-5

Polovina JJ, Kobayashi DR, Parker DM, Seki MP, Balazs GH (2000) Turtles on the edge: movement of loggerhead turtles (Caretta caretta) along oceanic fronts, spanning longline fishing grounds in the central North Pacific, 1997 1998. Fish Oceanogr 9:71-82

Polovina JJ, Howell E, Kobayashi DR, Seki MP (2001) The transition zone chlorophyll front, a dynamic global feature defining migration and forage habitat for marine resources. Prog Oceanogr 49:469-483

Polovina JJ, Howell E, Parker DM, Balazs GH (2003) Divedepth distribution of loggerhead (Carretta carretta) and olive ridley (Lepidochelys olivacea) sea turtles in the central North Pacific: Might deep longline sets catch fewer turtles? Fish Bull 101:189-193

Polovina JJ, Balazs GH, Howell EA, Parker DM, Seki MP,
Dutton PH (2004) Forage and migration habitat of loggerhead (Caretta caretta) and olive ridley (Lepidochelys olivacea) sea turtles in the central North Pacific Ocean. Fish Oceanogr 13:36-51

Polovina J, Uchida I, Balazs G, Howell EA, Parker D, Dutton P (2006) The Kuroshio Extension Bifurcation Region: a pelagic hotspot for juvenile loggerhead sea turtles. DeepSea Res II 53:326-339

Ramirez-Cruz JC, Ramirez IP, Flores DV (1991) Distribución y abundancia de la tortuga perica, Caretta caretta Linnaeus (1758), en la costa occidental de Baja California Sur, Mexico. Archelon 1:1-4

Reich KJ, Bjorndal KA, Bolten AB (2007) The 'lost years' of green turtles: using stable isotopes to study cryptic lifestages. Biol Lett 3:712-714

Shoop CR, Ruckdeschel C (1982) Increasing turtle strandings in the southeast United-States - a complicating factor. Biol Conserv 23:213-215

Skulason S, Smith TB (1995) Resource polymorphisms in vertebrates. Trends Ecol Evol 10:366-370

Smith RC, Dustan P, Au D, Baker KS, Dunlap EA (1986) Distribution of cetaceans and sea-surface chlorophyll concentrations in the California Current. Mar Biol 91:385-402

Snover ML (2002) Growth and ontogeny of sea turtles using skeletochronology: methods, validation and application to conservation. PhD dissertation, Duke University, Durham, $\mathrm{NC}$

Stearns SC (1996) The evolution of life histories. Oxford University Press, Oxford

Stephens DW, Krebs JR (1986) Foraging theory. Princeton University Press, Princeton, NJ

SYSTAT (2007) SYSTAT 12. SYSTAT Software, Chicago, IL

- Szaniawska A, Wolowicz M (1986) Changes in the energy content of common species from Hornsund, Southwest Spitsbergen. Polar Res 4:85-90

Tiwari M, Bjorndal KA (2000) Variation in morphology and reproduction in loggerheads, Caretta caretta, nesting in the United States, Brazil, and Greece. Herpetologica 56: $343-356$

Tomas J, Aznar FJ, Raga JA (2001) Feeding ecology of the loggerhead turtle Caretta caretta in the western Mediterranean. J Zool 255:525-532

Tremblay Y, Shaffer SA, Fowler SL, Kuhn CE and others (2006) Interpolation of animal tracking data in a fluid environment. J Exp Biol 209:128-140

Van Buskirk J, Crowder LB (1994) Life-history variation in marine turtles. Copeia 1994:66-81

Votier SC, Bearhop S, Ratcliffe N, Phillips RA, Furness RW (2004) Predation by great skuas at a large Shetland seabird colony. J Appl Ecol 41:1117-1128

Wallace BP, Jones TT (2008) What makes marine turtles go: a review of metabolic rates and their consequences. J Exp Mar Biol Ecol 356:8-24

> Wallace BP, Kilham SS, Paladino FV, Spotila JR (2006) Energy budget calculations indicate resource limitation in Eastern Pacific leatherback turtles. Mar Ecol Prog Ser 318: 263-270

Werner EE, Gilliam JF (1984) The ontogenetic niche and species interactions in size structured populations. Annu Rev Ecol Syst 15:393-425

Wetherall JA, Balazs GH, Tokunaga RA, Yong MYY (1993) Bycatch of marine turtles in North Pacific high seas driftnet fishery and impacts on stock. In: Ito J (ed) INPFC symposium on biology, distribution and stock assessment of species caught in the high seas driftnet fishery in the North Pacific Ocean. International North Pacific Fisheries Commision, Vancouver, p 519-538

Zug GR, Balazs GH, Wetherall JA (1995) Growth in juvenile loggerhead sea turtles (Caretta caretta) in the North Pacific pelagic habitat. Copeia 1995:484-487 